\title{
Article \\ The Spatial and Temporal Characteristics of Urban Heat Island Intensity: Implications for East Africa's Urban Development
}

\author{
Xueqin $\mathrm{Li}^{1, *}$, Lindsay C. Stringer ${ }^{1}\left(\mathbb{D}\right.$ and Martin Dallimer ${ }^{2} \mathbb{C}$ \\ 1 Department of Environment and Geography, University of York, York YO10 5NG, UK; \\ lindsay.stringer@york.ac.uk \\ 2 School of Earth and Environment, University of Leeds, Woodhouse Lane, Leeds LS2 9JT, UK; \\ M.Dallimer@leeds.ac.uk \\ * Correspondence: x13053@york.ac.uk
}

Citation: Li, X.; Stringer, L.C.; Dallimer, M. The Spatial and Temporal Characteristics of Urban Heat Island Intensity: Implications for East Africa's Urban Development. Climate 2021, 9, 51. https://doi.org/ $10.3390 /$ cli9040051

Academic Editors: Giulia Ulpiani and Michele Zinzi

Received: 3 March 2021

Accepted: 24 March 2021

Published: 28 March 2021

Publisher's Note: MDPI stays neutral with regard to jurisdictional claims in published maps and institutional affiliations.

Copyright: (c) 2021 by the authors. Licensee MDPI, Basel, Switzerland. This article is an open access article distributed under the terms and conditions of the Creative Commons Attribution (CC BY) license (https:// creativecommons.org/licenses/by/ $4.0 /)$.

\begin{abstract}
Due to the combination of climate change and the rapid growth in urban populations in Africa, many urban areas are encountering exacerbated urban heat island (UHI) effects. It is important to understand UHI effects in order to develop suitable adaptation and mitigation strategies. However, little work has been done in this regard in Africa. In this study, we compared surface UHI (SUHI) effects between cities located in different climate zones in East Africa, investigating how they change, both spatially and temporally. We quantified the annual daytime and night-time SUHI intensities in the five most populated cities in East Africa in 2003 and 2017, and investigated the links to urban area size. We consider the possible drivers of SUHI change and consider the implication for future development, highlighting the role of factors such as topography and building/construction materials. We suggest that UHI mitigation strategies targeting East African cities may benefit from more comprehensive analyses of blue and green infrastructure as this offers potential opportunities to enhance human comfort in areas where UHI effects are highest. However, this needs careful planning to avoid increasing associated issues such as disease risks linked to a changing climate.
\end{abstract}

Keywords: urbanisation; climate; cities; densification; mitigation; population; temperature

\section{Introduction}

More than half of the world's population was residing in urban areas in 2018, with 4.2 billion people living in urban settlements. As the world continues to urbanise, this proportion is expected to increase from 55\% to 68\% between 2018 and 2050 [1]. One major challenge in coping with urbanisation is the urban heat island (UHI) effect: a phenomenon in which urban areas are warmer than their adjacent rural areas [2]. Air UHI (AUHI) and surface UHI (SUHI) are two major indicators used in UHI analysis. AUHI is based on air temperature measurements above or below the roof level, whereas SUHI is derived from remotely sensed surface temperatures. Here, we focus on the SUHI. The UHI effect is caused by differences in urban and rural energy balance [3]. Compared to rural areas, impervious surfaces in urban areas have lower albedo, and higher thermal capacity and thermal conductivity [4-6]. Urban structures and their configurations can also raise the surface roughness, trapping radiation in built-up areas, and changing overall air movement [5], with precinct ventilation performance further influencing the UHI and thermal comfort [7].

The UHI effect brings about numerous direct and indirect impacts on urban inhabitants, primarily affecting their health $[5,8,9]$. In particular, the UHI effect exposes urban inhabitants to additional heat stress, generating extra thermal discomfort in many cities under particular urban development patterns and geographic conditions, and increasing heat-related health risks [10]. Generally, the UHI effect prolongs and intensifies heat waves, which increases morbidity and mortality during the heatwave events [11,12]. 
Warming intensified by urban land use and land cover change has been identified in many cities, which implies that heat stresses will be further exacerbated in the future $[5,13]$, as the urbanisation trend continues. For example, the UHI effect became more prominent in areas of rapid urbanisation in the Pearl River Delta of China [14]; SUHI was found to be influenced by urban land use in Rotterdam in the Netherlands [15]; and amplified temperatures detected in Noida, India, were mainly due to an increase in impervious areas, associated with urbanisation [16]. The impacts caused by the UHI effect will be exacerbated when taking climate change into consideration $[5,8,17]$. The interactions of UHI effect and climate change are non-linear [5], and are not simply the sum of the combined contributions [18].

Enhancement of UHI intensity has been detected in various cities around the world. Planners have devised models at different scales for conceptualising UHI effect and urban growth. However, the major focus of these studies is on expansion forms of urban growth, rather than densification [19]. In contrast, urban densification targets higher urban density. This approach can lead to economic efficiency and resource conservation as services and infrastructure are more easily integrated into more densely built cities. Urban expansion is usually associated with urban sprawl, which is a kind of rapid urban land expansion with non-contiguous and unplanned development. Urban sprawl is exemplified via unlimited outward expansion, and rapid growth toward suburban areas [20]. Urban sprawl brings numerous challenges for urban development, including unsustainable land use problems, pollution, and environmental degradation [21]. In developing countries of Africa and Asia, rapid urban expansion has become a critical public policy issue in recent years [22]. Urban expansion mainly contributes to the broadening of the area affected by the UHI, while densification is likely to exacerbate the intensity of the UHI effect [23]. Although urban expansion has become the most common form of urban development, some African countries have adopted policies that aim to promote urban densification [24-26].

Many countries with the fastest estimated and projected rates of urbanisation are located in Africa [1], where rapid and often unplanned urbanisation is exacerbating the impacts of a wide range of natural and anthropogenic disasters. The East Africa region is one of Africa's fastest urbanising areas and its growth rate is higher than the average for Africa. Estimates from the United Nations (UN) show that $24 \%$ of East Africa's population lives in urban areas in 2018, compared to only 7\% in 1960; this represents an increase from 3 million people in 1960 to 65 million urban inhabitants in 2018 [1]. As East Africa continues to urbanise, the proportion of urban populations is expected to increase from $24 \%$ to $39 \%$ by 2050. The urban poor who live in informal settlements are highly susceptible to heat stress, and are particularly vulnerable to sustained high temperatures due to their location, urban design and poverty levels. As urban area growth and climate change intensify, hundreds of millions of inhabitants will be under heat stress. For example, over 70 million people in Kenya and Uganda experienced 20 to 25 days of extreme heat per year in 2018, yet it could exceed 125 days by 2090, putting far more people at risk [27].

Climate change leads to higher temperatures and longer, more severe, and more frequent heat waves, causing UHI affected areas to bear the brunt of these harsher heat events. East Africa has been identified as one of the most vulnerable regions in Africa in the face of climate change [28]. Most of the East African region has experienced a significant temperature increase from the beginning of the early 1980s [29]. The Famine Early Warning Systems Network (FEWS NET) also reported temperature increases in many areas of Ethiopia, Kenya, South Sudan, and Uganda over the last 50 years [30]. Temperatures in large parts of East Africa are projected to rise during the current century, and the maximum and minimum temperatures will be higher than the baseline period (1961 to 1990) [28]. Climate model projections under the SRES A2 and B1 scenarios indicate temperature increases in all seasons across the whole of Ethiopia, which may lead to a higher frequency of heat waves as well as higher rates of evaporation and evapotranspiration [31].

The UHI effect has become one of the clearest examples of how urbanisation affects the local and regional climate [19]. Therefore, essential measures should be taken to 
reduce the negative effects of UHI, especially in the coming decades, where the frequency and intensity of extreme heat events are anticipated to become more severe due to the interactions between urban climate, heatwaves, global climate change, and anticipated rapid urbanisation [5]. Globally, the UHI effect has been extensively studied, however most research has been conducted in cities located in Europe, North America and China, while there has been little research in those regions most vulnerable to climate change, such as cities in Africa [19]. Most UHI studies also tend to focus on a single city. Variability in methodological approaches can make direct comparisons across studies (and therefore cities) difficult, making it harder to build a picture of regional changes. This is problematic because climate conditions are important factors, affecting UHI in different ways [32]. To understand more about the importance of regional climate conditions and patterns of urbanisation in determining the extent and distribution of UHI effects, it is important to undertake analyses across multiple cities simultaneously using a common methodology. Thus far, however, few such studies exist.

Given that the combined impacts of urbanisation and climate change will potentially have large impacts on future urban temperatures [19] and exacerbate existing heat stress in East African cities, understanding the UHI effect in these cities is important if UHI is to be mitigated. This study compares SUHI between East African cities located in different climate zones and assess how it changes spatially and temporally. This allows us to understand the possible driving factors, and consider the implications for future urban development. We address the following questions: (1) How does SUHI vary in different climate zones in East Africa? (2) What are the spatial and temporal variations of SUHI in these cities and what are the possible driving factors? (3) What are the implications for future urban development in the region?

\section{Materials and Methods}

\subsection{Study Area}

Five cities spanning the four climate zones in the region were selected as study areas based on the following criteria [33]: (i) being the largest or capital city; (ii) being the main economic and commercial centre of their country; and (iii) experiencing rapid urbanisation with the highest population in their respective countries. The location of these cities and the corresponding climatic information (en.climate-data.org) and recorded urban development pattern are provided in Table 1, Table 2 and Figure 1. Climate classification data was taken from $1 \mathrm{~km}$ resolution Köppen-Geiger maps [34].

Table 1. Geographic and climatic information of the study cities.

\begin{tabular}{|c|c|c|c|c|c|c|c|}
\hline \multirow{2}{*}{ City } & \multirow{2}{*}{$\begin{array}{l}\text { Population } \\
\text { (2015) }\end{array}$} & \multirow{2}{*}{$\begin{array}{l}\text { Longitude/ } \\
\text { Latitude }\end{array}$} & \multirow{2}{*}{$\begin{array}{c}\text { Altitude } \\
\text { (Meters about } \\
\text { Sea Level) }\end{array}$} & \multirow{2}{*}{$\begin{array}{c}\text { Annual } \\
\text { Rainfall } \\
(\mathrm{mm})\end{array}$} & \multicolumn{3}{|c|}{ Temperature $\left({ }^{\circ} \mathrm{C}\right)$} \\
\hline & & & & & Annual & Maximun & Minimum \\
\hline $\begin{array}{l}\text { Khartoum } \\
\text { (Sudan) }\end{array}$ & $5,128,000$ & $\begin{array}{l}32.527^{\circ} \mathrm{E} \\
15.522^{\circ} \mathrm{N}\end{array}$ & 386 & 70 & 29.9 & 34.3 (May) & 22.7 (Jaunuary) \\
\hline $\begin{array}{l}\text { Dar es Salaam } \\
\text { (Tanzania) }\end{array}$ & $5,116,000$ & $\begin{array}{l}39.103^{\circ} \mathrm{E} \\
-6.807^{\circ} \mathrm{S}\end{array}$ & 16 & 1114 & 26.1 & $\begin{array}{c}27.9 \\
\text { (February) }\end{array}$ & 24.4 (July) \\
\hline $\begin{array}{l}\text { Nairobi } \\
\text { (Kenya) }\end{array}$ & $3,914,000$ & $\begin{array}{l}36.858^{\circ} \mathrm{E} \\
-1.181^{\circ} \mathrm{S}\end{array}$ & 1669 & 674 & 18.8 & 17 (July) & $\begin{array}{c}20.5 \text { (February or } \\
\text { March) }\end{array}$ \\
\hline $\begin{array}{l}\text { Addis Ababa } \\
\text { (Ethiopia) }\end{array}$ & $3,871,000$ & $\begin{array}{l}38.565^{\circ} \mathrm{E} \\
8.884^{\circ} \mathrm{N}\end{array}$ & 2350 & 1874 & 15.6 & 17.2 (April) & 14.1 (December) \\
\hline $\begin{array}{l}\text { Kampala } \\
\text { (Uganda) }\end{array}$ & $2,577,000$ & $\begin{array}{l}32.596^{\circ} \mathrm{E} \\
0.291^{\circ} \mathrm{N}\end{array}$ & 1224 & 1747 & 21.4 & $\begin{array}{c}22.7 \\
\text { (February) }\end{array}$ & 20.7 (July) \\
\hline
\end{tabular}


Table 2. Climate zones and urban development information of the study cities.

\begin{tabular}{|c|c|c|c|}
\hline City & Climate Zone & Climate Condition & Urban Development Pattern \\
\hline Khartoum (Sudan) & Warm desert climate & $\begin{array}{l}\text { There are three seasons in the } \\
\text { city, a dry season from } \\
\text { November to February, hot } \\
\text { season from March to May, } \\
\text { and a wet season from June to } \\
\text { October [35]. }\end{array}$ & $\begin{array}{l}\text { The development of the city is } \\
\text { tightly linked to the evolution of } \\
\text { the Blue and White Nile Rivers, } \\
\text { and is also influenced by } \\
\text { increasing land exploitation for } \\
\text { intensive and extensive } \\
\text { cultivation [36]. }\end{array}$ \\
\hline Dar es Salaam (Tanzania) & Tropical savannah climate & $\begin{array}{l}\text { The climate of the city is } \\
\text { greatly influenced by the } \\
\text { northeast monsoon which } \\
\text { prevails from March to } \\
\text { October. The southeast } \\
\text { monsoon dominates between } \\
\text { October and March. The } \\
\text { climate is also greatly } \\
\text { influenced by the sea due to } \\
\text { proximity of the city to the } \\
\text { Indian Ocean [37]. }\end{array}$ & $\begin{array}{l}\text { Due to its location along the coast } \\
\text { and the existence of the four main } \\
\text { roads entering the city, Dar es } \\
\text { Salaam has been observed to } \\
\text { expand in a radial structure [37]. } \\
\text { The city is experiencing multiple } \\
\text { development projects involving } \\
\text { partnerships between the } \\
\text { government and UN HABITAT. } \\
\text { These projects aim to reduce the } \\
\text { area of unplanned settlements } \\
\text { [37]. }\end{array}$ \\
\hline Nairobi (Kenya) & $\begin{array}{l}\text { Subtropical oceanic highland } \\
\text { climate }\end{array}$ & $\begin{array}{l}\text { The city experiences a short } \\
\text { rainy period in } \\
\text { November/December and a } \\
\text { heavy rainy season from } \\
\text { March till the beginning of } \\
\text { June [38]. }\end{array}$ & $\begin{array}{l}\text { With functionalism as the main } \\
\text { planning principle, the city has } \\
\text { grown in concentric zones [33,39]. } \\
\text { More than half the population } \\
\text { reside in informal settlements [40]. } \\
\text { The city is served by a highly } \\
\text { polluted river (the Nairobi River) } \\
\text { and exhibits ahigh proportion of } \\
\text { open vegetated spaceswithin the } \\
\text { urban area [40]. }\end{array}$ \\
\hline Addis Ababa (Ethiopia) & $\begin{array}{c}\text { Humid subtropical } \\
\text { climate/Subtropical oceanic } \\
\text { highland climate }\end{array}$ & $\begin{array}{l}\text { The short rainy season } \\
\text { extends from March to May } \\
\text { and the main rainy season } \\
\text { from June to September, } \\
\text { followed by a dry season from } \\
\text { October to February [41,42]. }\end{array}$ & $\begin{array}{l}\text { The city is experiencing rapid } \\
\text { urbanisation, with increasing } \\
\text { built-up area (impervious } \\
\text { surfaces), and is characterized by } \\
\text { mixed land uses dominated by } \\
\text { informal settlements located close } \\
\text { to urban growth centers [33]. }\end{array}$ \\
\hline Kampala (Uganda) & Tropical rainforest climate & $\begin{array}{l}\text { There are two wet seasons } \\
\text { (March-May and } \\
\text { September-November). } \\
\text { Torrential rains are often } \\
\text { observed from March to May } \\
\text { and July is normally the driest } \\
\text { month [43]. }\end{array}$ & $\begin{array}{c}\text { The city has expanded in all } \\
\text { directions with growth primarily } \\
\text { concentrated along main roads. } \\
\text { Between } 1989 \text { and } 2010 \text { the total } \\
\text { built-up area increased } \\
\text { exponentially, a result of both } \\
\text { natural increase and migration } \\
{[43,44] .}\end{array}$ \\
\hline
\end{tabular}




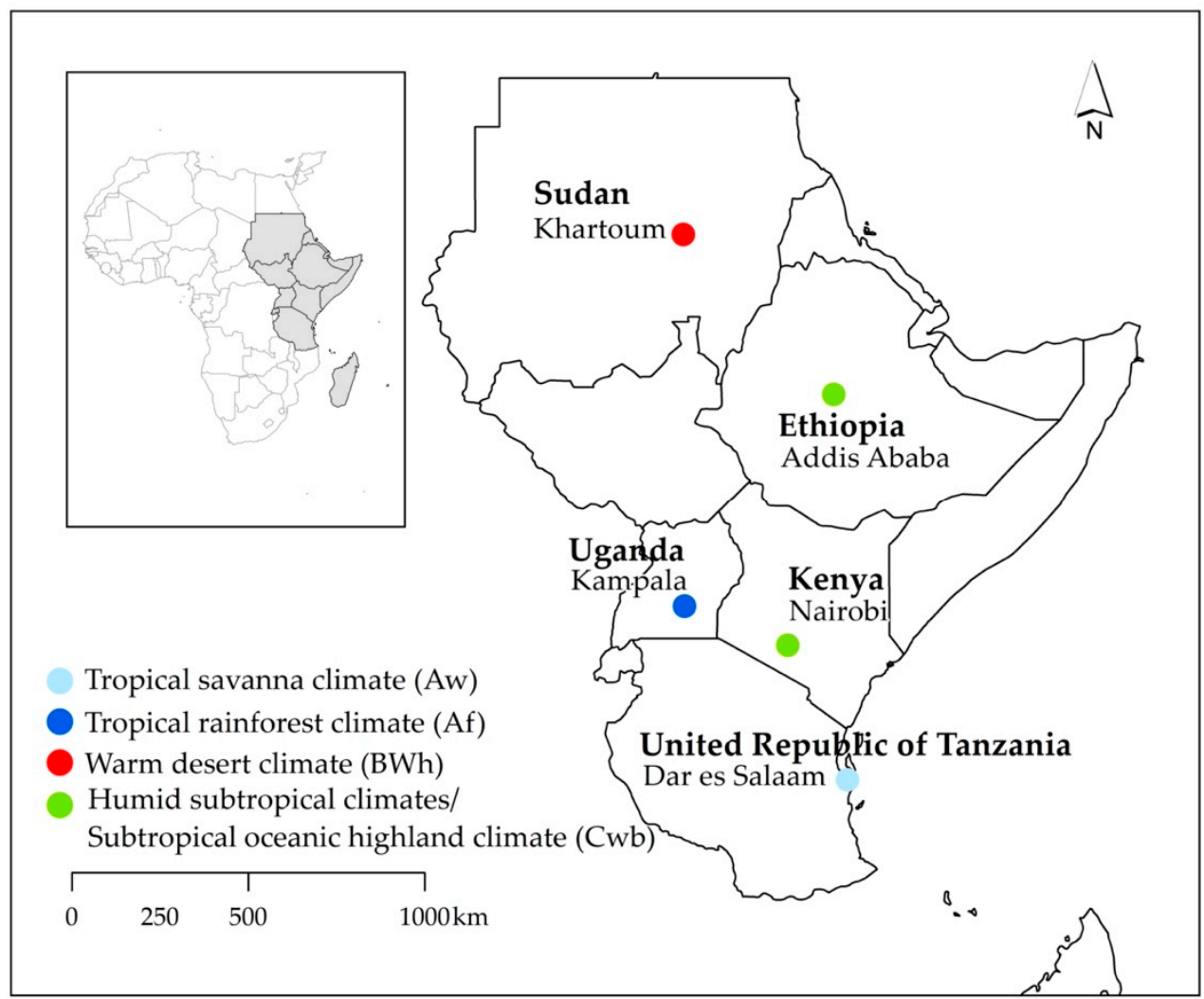

Figure 1. The location of study area and Africa.

\subsection{Data and Methodology}

The definition of urban and non-urban for SUHI estimation is based on data from Landscan urban extent (Natural Earth; https: / / www.naturalearthdata.com/, (accessed on 1 May 2020). City centres were defined as the centre of the most populated areas in each city. Urban units are closed polygons around contiguous urban agglomerations. An advantage of using this dataset is that it is based on a consistent algorithm implemented on the MODIS land use satellite. It also consistently bounds global hotspots of human habitation. This approach is also more appropriate than using administrative boundaries, as the urban areas of many developing countries have expanded rapidly and do not always map directly onto administrative jurisdictions. Administrative boundaries are also not comparable across East Africa's cities, and often do not include the full extent of the urban areas [33].

We used the Global Surface UHI Explorer to quantify SUHI. The Global Surface UHI Explorer is based on the Simplified Urban Extent (SUE) algorithm [45], which defines the SUHI as the average LST difference between the urban and non-urban pixels, as classified from spectral reflectance data, within an urban agglomeration or city [45].

The SUE uses the MODIS-derived LST data from TERRA (MOD11A2) and AQUA (MYD11A2). After selecting clear-sky pixels with average LST error of less than or equal to 3 K for quality control, data estimated the LST at four local times: 01:30, 10:30, 13:30, and 22:30. Day time and night-time SUHI varies according to different climate conditions, so we focus on annual daytime and night-time SUHI here. Based on Global Multi-resolution Terrain Elevation Data 2010 (GMTED2010), the SUE eliminated the influence of the elevation differences, by filtering to only include those clusters with a mean elevation difference of less than $50 \mathrm{~m}$ [45].

Data from the TERRA platform is available from February 2000 until the present, and data from AQUA is available from July 2002 to the present. As data in the Global Surface UHI Explorer version 3 was only available from 2003 to 2017, we chose the years 2003 and 2017 for observation [45]. 
The Welch's Test (unequal variance) was conducted to see if two years of UHI are significantly different. Welch's Test is a modification of the Student's $t$-test that performs better than the Student's $t$-test whenever sample sizes and variances are unequal between groups, and gives the same result when sample sizes and variances are equal [46].

$$
x=\frac{\overline{X_{1}}-\overline{X_{2}}}{\sqrt{\frac{S_{1}^{2}}{N_{1}}+\frac{S_{2}^{2}}{N_{2}}}}
$$

The degrees of freedom of the Welch $t$-test is estimated as follows:

$$
d f=\frac{\left(\frac{S_{1}^{2}}{N_{1}}+\frac{S_{2}^{2}}{N_{2}}\right)^{2}}{\left(\frac{S_{1}^{4}}{N_{1}^{2}\left(N_{1}-1\right)}+\frac{S_{2}^{4}}{N_{2}^{2}\left(N_{2}-1\right)}\right)}
$$

$\overline{X_{j}}=$ sample mean,

$S_{j=}=$ sample deviation,

$N_{j}=$ sample size, $j \in\{1,2\}$

We set a null hypothesis that 15 years of urban development did not change the UHI intensity. We used Hedges' $g$ (the unbiased version of Cohen's d) to compute the effect size for different years' UHI with different sample sizes (n) [47], by adjusting the calculation of the pooled standard deviation with weights for the sample sizes.

$$
\text { Hedges }^{\prime} g=\frac{M_{1}-M_{2}}{S D_{\text {pooled }}^{*}}
$$

$M_{1}-M_{2}=$ difference in means,

$S D_{\text {pooled }}^{*}=$ pooled and weighted standard deviation,

Overall this approach is identical to Cohen's d with a correction of a positive bias in the pooled standard deviation $[48,49]$. The result of Hedges' $\mathrm{g}$ is represented by gHedge in the subtitle of each plot in Tables 4 and 5 [50]. We draw on the suggestions of Cohen (1988) for interpreting the magnitude of effect sizes, whereby intervals for Cohen's d under 0 : negative effect; 0 to 0.2 : no effect; 0.2 to 0.5 : small effect; 0.5 to 0.8 : intermediate effect; 0.8 and higher: strong effect [48]. All the statistics analyses were undertaken in RStudio using the function ggbetweenstats from R package ggpubr [51].

\section{Results}

\subsection{Annual SUHI}

The results of SUHI intensity in 2003 and 2017 are shown in Table 3, Figures 2 and 3. The highest SUHI intensity in 2003 across the five cites was found in Kampala (tropical rainforest climate zone), followed by Nairobi (subtropical oceanic highland climate), Dar es Salaam (tropical savannah climate) and Addis Ababa (subtropical oceanic highland climate). Notably, Khartoum (warm desert climate) has a daytime SUHI of below zero, indicating that the city was cooler than its surrounds. This SUHI sequence demonstrated a slight change in 2017, when Kampala (tropical rainforest climate) still exhibited the highest annual UHI intensity but Dar es Salaam (tropical savannah climate) rose to second place followed by Nairobi (subtropical oceanic highland climate). The annual SUHI intensity for Addis Ababa (subtropical oceanic highland climate) had become the lowest except for Khartoum which was still showing to be a UCI in 2017, with a below zero daytime SUHI. 
Table 3. SUHI intensity during daytime and night-time in the study cities in 2003 and 2017. The $\mathrm{n}$ value is the number of UHI pixels.

\begin{tabular}{ccccccccc}
\hline & \multicolumn{3}{c}{ Annual Daytime SUHI $\left({ }^{\circ} \mathbf{C}\right)$} & \multicolumn{2}{c}{ Annual Night-Time SUHI $\left({ }^{\circ} \mathbf{C}\right)$} \\
\cline { 2 - 9 } City & $\mathbf{2 0 0 3}$ & $\mathbf{2 0 1 7}$ & \multicolumn{2}{c}{$\mathbf{2 0 0 3}$} & \multicolumn{2}{c}{$\mathbf{2 0 1 7}$} \\
\hline Khartoum & 446 & -0.44 & 640 & -0.34 & 446 & 1.01 & 640 & 1.1 \\
Intensity & $\mathbf{n}$ & $\begin{array}{c}\text { SUHI } \\
\text { Intensity }\end{array}$ & $\mathbf{n}$ & $\begin{array}{c}\text { SUHI } \\
\text { Intensity }\end{array}$ & $\mathbf{n}$ & $\begin{array}{c}\text { SUHI } \\
\text { Intensity }\end{array}$ \\
Addis Ababa & 131 & 0.17 & 254 & 0.42 & 131 & 0.25 & 254 & -0.13 \\
Kampala & 240 & 2.21 & 285 & 1.93 & 240 & 1.02 & 285 & 0.82 \\
Nairobi & 42 & 1.73 & 242 & 0.57 & 42 & 0.93 & 242 & 0.43 \\
Dar es Salaam & 131 & 0.89 & 173 & 1.85 & 131 & 0.26 & 173 & 0.3 \\
\hline
\end{tabular}

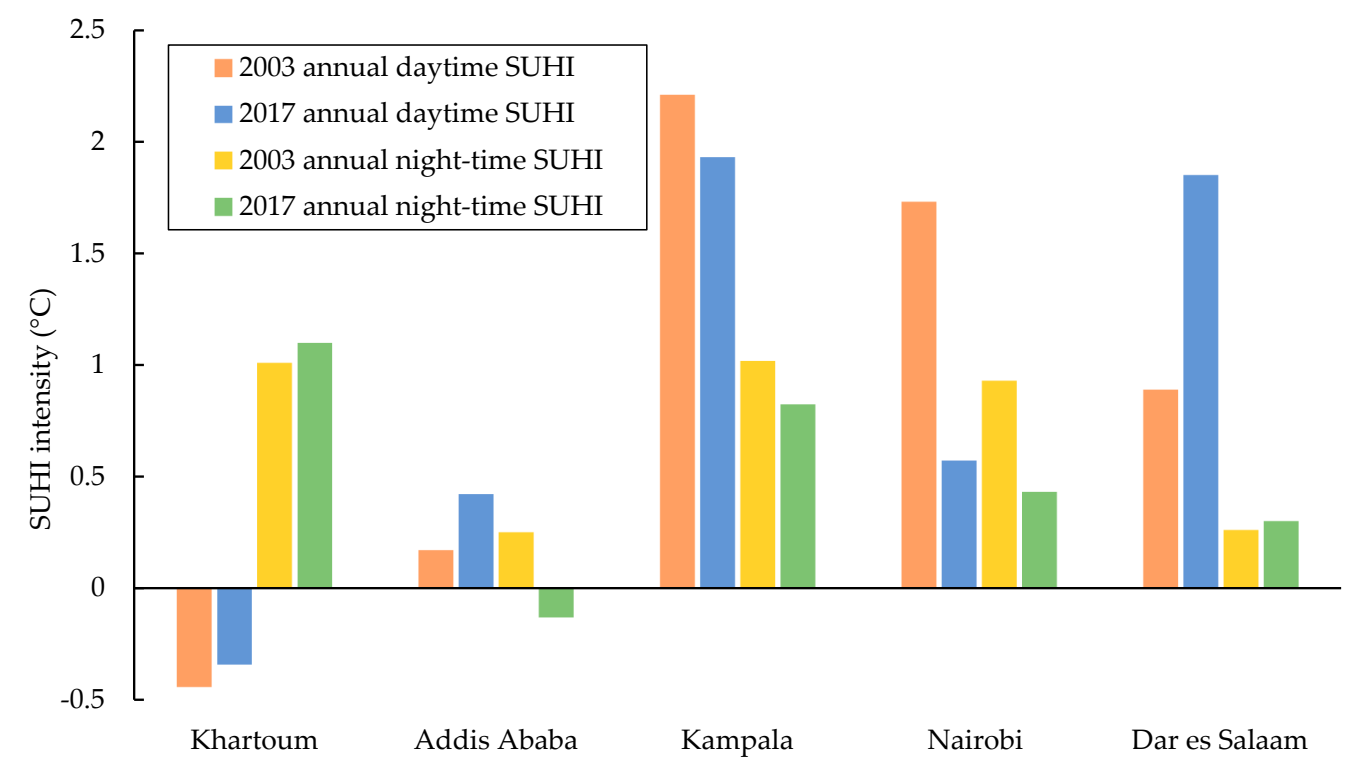

Figure 2. Daytime and night-time SUHI spatial distribution of each city in 2003 and 2017.

For annual night-time SUHI intensity in 2003, Kampala (tropical rainforest climate) still had the highest SUHI intensity. This was followed closely by Khartoum (warm desert climate), Nairobi (subtropical oceanic highland climate), Dar es Salaam (tropical savannah climate) and Addis Ababa (subtropical oceanic highland climate). In 2017, Khartoum (warm desert climate) showed the highest night-time SUHI intensity, followed by Kampala (tropical rainforest climate), Nairobi (subtropical oceanic highland climate), Dar es Salaam (tropical savannah climate) and then Addis Ababa (subtropical oceanic highland climate).

For all five cities, SUHI intensity and magnitude varied with time. In 2003, annual daytime UHI intensity observations were $-0.44{ }^{\circ} \mathrm{C}$ in Khartoum, $0.17^{\circ} \mathrm{C}$ in Addis Ababa, $2.21{ }^{\circ} \mathrm{C}$ in Kampala, $1.73{ }^{\circ} \mathrm{C}$ in Nairobi and $0.89^{\circ} \mathrm{C}$ in Dar es Salaam. Annual night-time SUHI intensity in 2003 was $-1.01{ }^{\circ} \mathrm{C}$ in Khartoum, $-0.25^{\circ} \mathrm{C}$ in Addis Ababa, $1.02{ }^{\circ} \mathrm{C}$ in Kampala, $0.93^{\circ} \mathrm{C}$ in Nairobi and $0.26^{\circ} \mathrm{C}$ in Dar es Salaam. In 2017, annual daytime SUHI intensity observations from GEE were $-0.34{ }^{\circ} \mathrm{C}$ in Khartoum, $0.42{ }^{\circ} \mathrm{C}$ in Addis Ababa, $1.93{ }^{\circ} \mathrm{C}$ in Kampala, $0.57{ }^{\circ} \mathrm{C}$ in Nairobi and $1.85^{\circ} \mathrm{C}$ in Dar es Salaam. Annual night-time SUHI intensity in 2017 was $1.1{ }^{\circ} \mathrm{C}$ in Khartoum, $-0.13{ }^{\circ} \mathrm{C}$ in Addis Ababa, $0.82{ }^{\circ} \mathrm{C}$ in Kampala, $0.43^{\circ} \mathrm{C}$ in Nairobi and $0.30{ }^{\circ} \mathrm{C}$ in Dar es Salaam. 
Daytime SUHI 2003
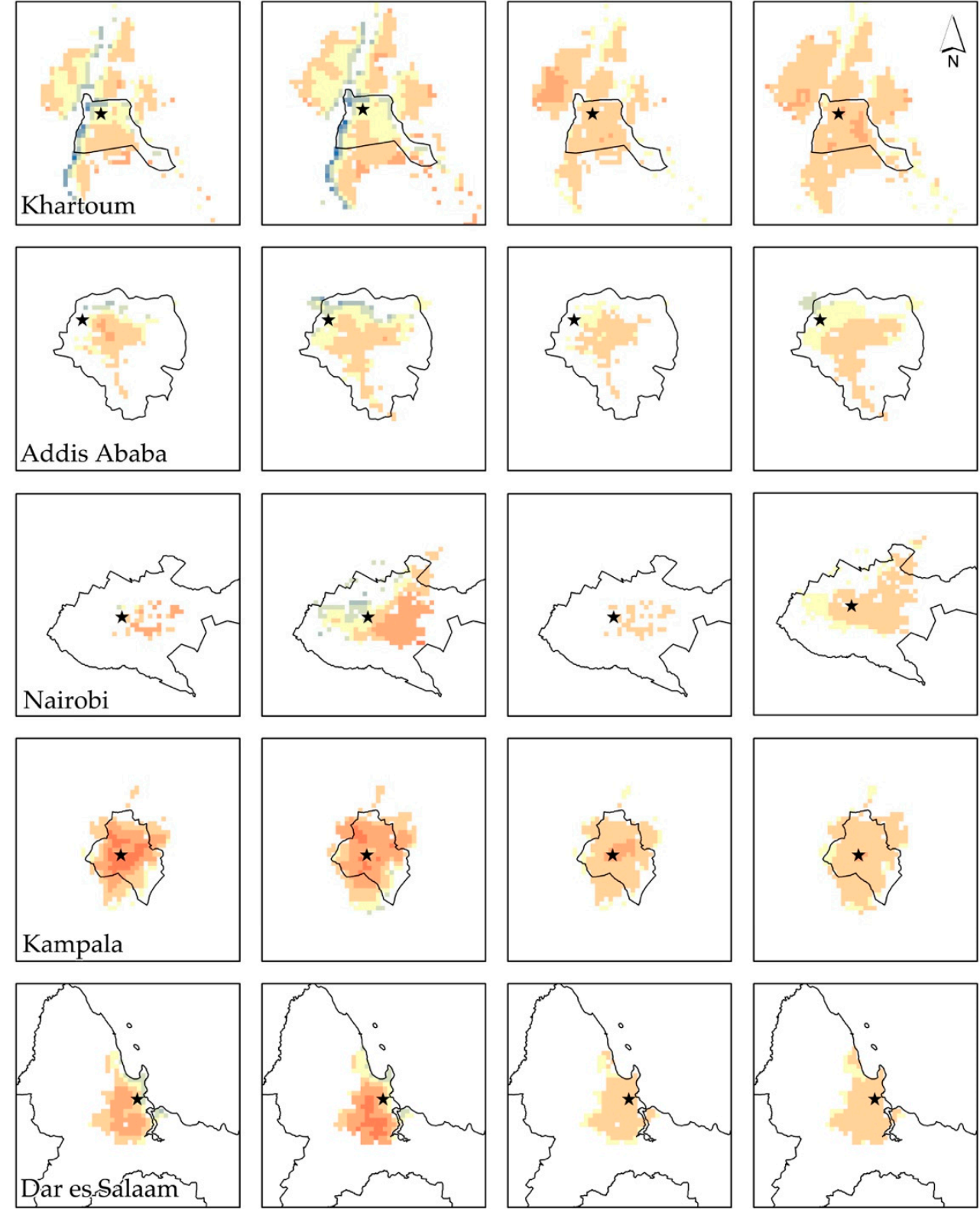

\section{SUHI intensity $\left({ }^{\circ} \mathrm{C}\right)$}

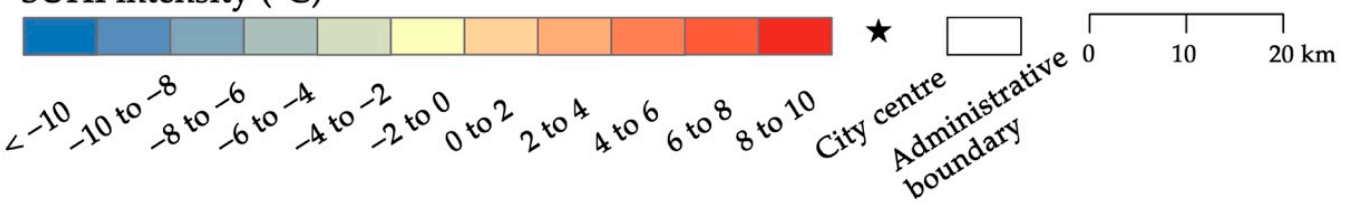

Figure 3. Daytime and night-time SUHI spatial distribution in each city in 2003 and 2017.

Addis Ababa, Kampala, Nairobi and Dar es Salaam demonstrate positive daytime SUHI intensity in 2003 while Khartoum, located within the warm desert climate, was found to demonstrate a surface urban cool island (SUCI) effect. In 2017, Kampala, Nairobi and Dar es Salaam still demonstrate a positive daytime SUHI intensity, while Addis Ababa shows a SUCI, as does Khartoum. All cities had positive night-time SUHI in 2003. This was true in 2017, except for Addis Ababa. The urban areas located in the humid subtropical climate changed from displaying a SUHI to SUCI. In 2003 and 2017, Kampala presents the highest daytime SUHI intensity and Khartoum demonstrates the lowest daytime SUCI. 
In contrast, Khartoum shows the highest SUHI intensity for the night-time while Addis Ababa has the lowest night-time SUHI intensity in 2003 and 2017.

Figure 3 shows the distribution of daytime and night-time SUHI intensity and magnitude in 2003 and 2017 for each of the five study areas. Compared to 2003, the urban area affected by SUHI has increased. For Khartoum, this area increased by $43.5 \%$, from 44,600 ha to 64,000 ha. In Addis Ababa, the SUHI-affected area rose from 13,100 ha in 2003 to 25,400 ha in 2017 , presenting a $93.9 \%$ increase. The largest change in the aerial extent of SUHI affected areas was for Nairobi, growing from 4,200 ha to 24,200 ha; an increase of $476.9 \%$. Changes were smallest in Kampala (24,000 ha to 28,500 ha; $18.8 \%)$ and Dar es Salaam (6.8\% from 16,200 ha to 17,300 ha).

From 2003 to 2017, the strength of SUCI in central areas of Khartoum, Nairobi and Dar es Salaam increased and the SUHI affected areas gradually expanded from the urban centre to the surrounding area. In Addis Ababa and Kampala, the SUHI intensity strength in central urban areas decreased and the affected areas reduced. In particular, in Kampala, the annual daytime SUHI intensity centre fragmented. There were two subsidiary SUHI centres in 2003, which became four separated SUHI centres, surrounding the urban area centre.

Annual night-time SUHI in Khartoum was positive and stronger than in other study cities. In 2003, the SUHI centre was located in the north west, and then moved toward the east, and in 2017 there were two SUHI centres in Khartoum located on the east side and middle west, divided by White Nile river. In 2003, the major SUHI centres in Addis Ababa and Nairobi were located south east of the cities, and their SUHI affected areas expanded and intensified in 2017. Night-time SUCI effect areas also expanded and intensified in 2017. Addis Ababa's SUCI expanded toward the urban north west, the same as the daytime SUHI expansion trajectory. However, Nairobi's night-time SUCI mostly expanded to the west, differing from the SUCI and daytime SUHI which appeared in north west side of the city. Compared to 2003, the area of the central city experiencing an annual night-time SUHI in Kampala shrank in 2017. However, as a whole a larger area of the city was affected by night-time SUHI. Night-time SUHI affected a larger area in Dar es Salaam in 2017, in a similar way to changes in daytime SUHI.

\subsection{Summary Statistics}

Figures 4 and 5 present daytime and night-time SUHI value distributions for each city in 2003 and 2017. A summary of annual mean, Welch's Test, and Hedges' g is provided in Tables 4 and 5. For Khartoum's urban areas located in a warm desert climate, the annual daytime SUHI was less intense than the night-time SUHI in 2003 and 2017. Daytime SUHI intensity increased significantly in Khartoum's urban areas over the last decade and a half, even though the expansion of urban areas over time would amplify the SUCI [39]. For Addis Ababa and Nairobi, both located in a humid subtropical climate, the annual daytime SUHI intensity was less than the night-time intensity in 2003 , and the annual daytime SUHI intensity was more pronounced than the night-time intensity in 2017. For Nairobi, also located in a humid subtropical climate zone, the annual daytime and nighttime SUHI intensities were greater than the night-time intensity both in 2003 and 2017. For Kampala and Dar es Salaam, annual daytime SUHI intensity was greater than the night-time intensity in 2003, and the annual daytime surface UHI intensity is stronger than the night-time intensity in 2017. 


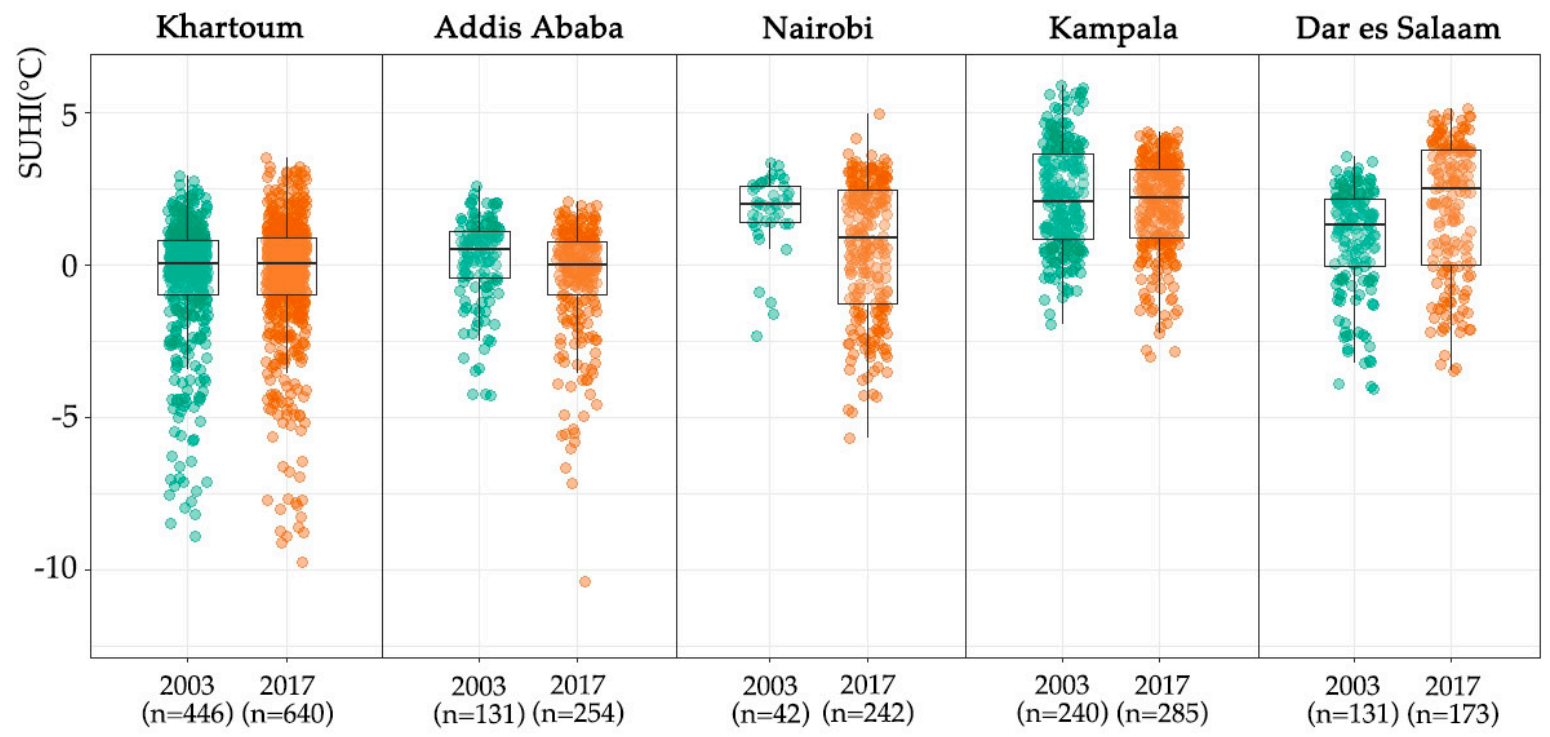

Figure 4. Daytime SUHI value distributions for each city in 2003 and 2017. The boxplots show the distribution of daytime SUHI in 2003 and 2017 in the five cities. The rectangle showing the ends of the first and third quartiles and central line the median. The $\mathrm{n}$ value under the $\mathrm{x}$-axis is the number of SUHI pixels.

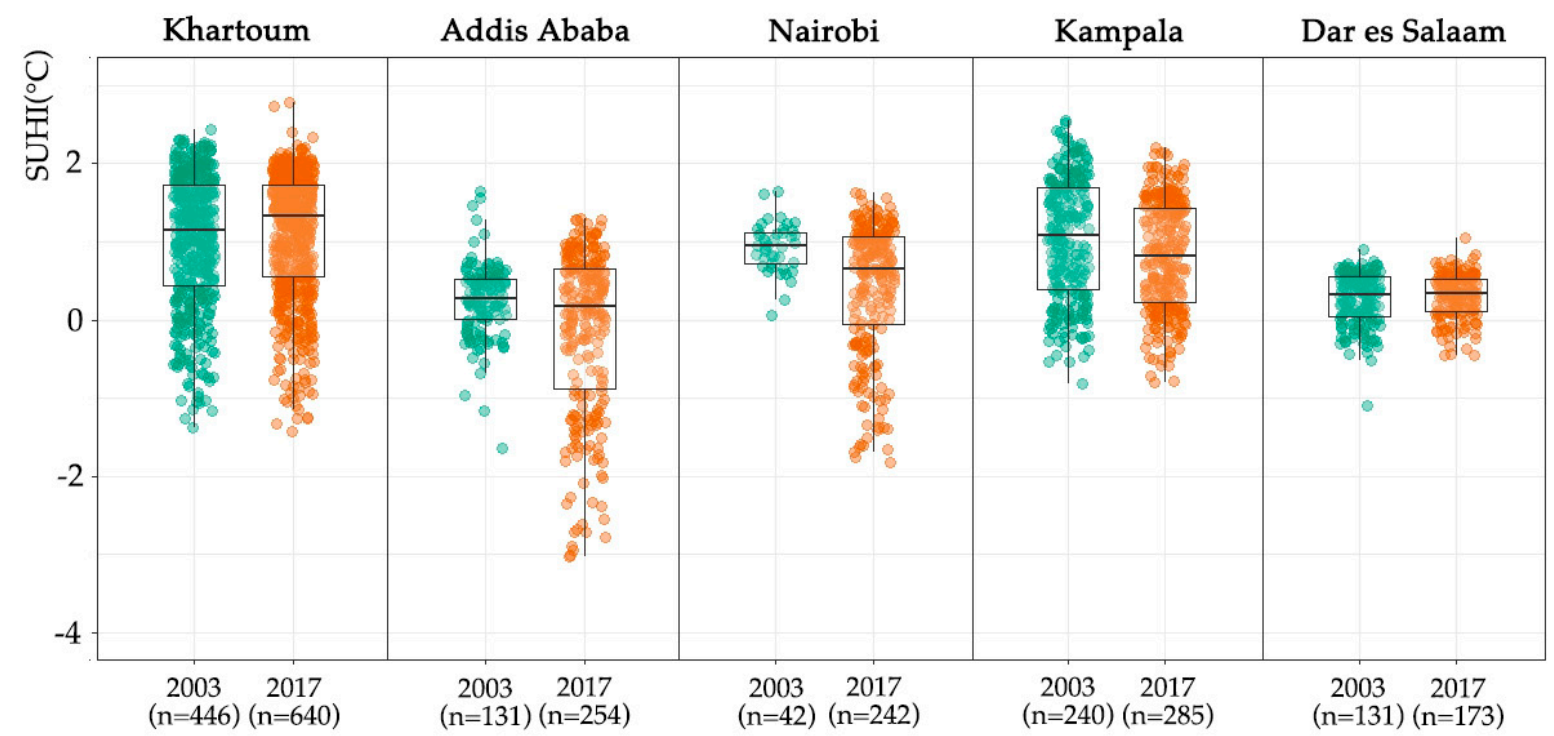

Figure 5. Night-time SUHI value distributions for each city in 2003 and 2017. The boxplots show the distribution of night-time SUHI in 2003 and 2017 in the five cities. The rectangle showing the ends of the first and third quartiles and central line the median. The $n$ value under the $\mathrm{x}$-axis is the number of SUHI pixels.

Table 4. Summary of annual daytime SUHI intensity statistics.

\begin{tabular}{|c|c|c|c|c|c|c|c|c|c|}
\hline \multirow{3}{*}{ City } & \multicolumn{6}{|c|}{ Daytime SUHI Intensity $\left({ }^{\circ} \mathrm{C}\right)$} & & & \multirow{3}{*}{ Hedges' g } \\
\hline & \multicolumn{2}{|c|}{ Maximum } & \multicolumn{2}{|c|}{ Minimum } & \multicolumn{2}{|c|}{ Annual Mean } & \multicolumn{2}{|c|}{ Welch's Test } & \\
\hline & 2003 & 2017 & 2003 & 2017 & 2003 & 2017 & & & \\
\hline Khartoum & 2.94 & 3.51 & -8.91 & -9.76 & -0.44 & -0.34 & -0.79 & $p=0.43$ & -0.05 \\
\hline Addis Ababa & 2.6 & 2.08 & -4.28 & -10.39 & 0.17 & -0.42 & 3.45 & $p=0.001$ & 0.36 \\
\hline Kampala & 5.9 & 4.38 & -1.93 & -2.99 & 2.21 & 1.93 & 1.93 & $p=0.054$ & 0.17 \\
\hline Nairobi & 3.35 & 4.96 & -2.36 & -5.68 & 1.73 & 0.57 & 4.86 & $p \leq 0.001$ & 0.65 \\
\hline Dar es Salaam & 3.59 & 5.15 & -4.07 & -3.49 & 0.89 & 1.85 & -4.39 & $p \leq 0.001$ & -0.48 \\
\hline
\end{tabular}


Table 5. Summary of annual night-time SUHI intensity statistics.

\begin{tabular}{|c|c|c|c|c|c|c|c|c|c|}
\hline \multirow{3}{*}{ City } & \multicolumn{6}{|c|}{ Night-Time SUHI Intensity $\left({ }^{\circ} \mathrm{C}\right)$} & \multirow{3}{*}{\multicolumn{2}{|c|}{ Welch's Test }} & \multirow{3}{*}{ Hedges' g } \\
\hline & \multicolumn{2}{|c|}{ Maximum } & \multicolumn{2}{|c|}{ Minimum } & \multicolumn{2}{|c|}{ Annual Mean } & & & \\
\hline & 2003 & 2017 & 2003 & 2017 & 2003 & 2017 & & & \\
\hline Khartoum & 2.43 & 2.77 & -1.38 & -1.42 & 1.01 & 1.1 & -1.63 & $p=0.103$ & -0.1 \\
\hline Addis Ababa & 1.64 & 1.29 & -1.64 & -3.03 & 0.25 & -0.13 & 4.92 & $p \leq 0.001$ & 0.47 \\
\hline Kampala & 2.55 & 2.21 & -0.82 & 0.79 & 1.02 & 0.82 & 3.12 & $p=0.002$ & 0.27 \\
\hline Nairobi & 1.64 & 1.63 & 0.06 & -1.82 & 0.93 & 0.43 & 6.91 & $p<0.001$ & 0.8 \\
\hline Dar es Salaam & 0.91 & 1.05 & -1.09 & -0.46 & 0.26 & 0.30 & -1.22 & $p=0.225$ & -0.13 \\
\hline
\end{tabular}

From Table 4, Welch $t$-tests confirm that there was no statistically significant difference between 2003 and 2017 in terms of annual daytime UHI intensity for Khartoum and Kampala $(p>0.05)$. However, there is highly statistically significant difference between 2003 and 2017 annual daytime SUHI intensity in Addis Ababa $(p=0.001)$, Nairobi $(p \leq 0.001)$ and Dar es Salaam $(p \leq 0.001)$. The negative Hedges' $\mathrm{g}$ indicates that 15 years of land use change caused a negative effect in SUHI growth in Khartoum (Hedges' $\mathrm{g}=-0.05$ ) and Dar es Salaam (Hedges' $g=-0.48$ ). Different positive Hedges' g values indicate no size effect in Kampala (Hedges' $\mathrm{g}=0.36$ ), a small effect in Addis Ababa (Hedges' $\mathrm{g}=0.36$ ) and an intermediate effect size in Nairobi (Hedges' $\mathrm{g}=0.65$ ).

For night-time SUHI (Table 5), Welch $t$-tests indicate that there is no statistically significant difference between 2003 and 2017 annual night-time SUHI intensity for Khartoum and Dar es Salaam $(p>0.05)$. However, the difference between the 2003 and 2017 annual night-time SUHI intensity is statistically significant $(p<0.05)$ for Kampala. There is a highly statistically significant difference between the 2003 and 2017 annual daytime SUHI intensity in Addis Ababa $(p \leq 0.001)$ and Nairobi $(p \leq 0.001)$. The negative Hedges' g indicates that 15 years of land use change negatively affected SUHI growth in Khartoum (Hedges' $\mathrm{g}=-0.1$ ) and Dar es Salaam (Hedges' $\mathrm{g}=-0.13$ ). Different positive Hedges' $\mathrm{g}$ values indicate there is a small effect in Addis Ababa (Hedges' $\mathrm{g}=0.47$ ) and Kampala (Hedges' $\mathrm{g}=0.27$ ), and an intermediate effect size in Nairobi (Hedges' $\mathrm{g}=0.8$ ).

\section{Discussion}

\subsection{Climate Zones}

The spatial and temporal heterogeneity of the SUHI effect in East Africa is explicitly delineated in this study. Generally, the climate effects on SUHI could be explained by the differences in soil moisture [3,52]. The hot-wet cities (i.e., Kampala and Dar es Salaam) normally present higher soil moisture contents compared with desert cities (i.e., Khartoum) [53] and exhibit larger urban-rural differences in soil moisture, resulting in higher daytime and lower night-time LST differences between urban and surrounding rural areas (i.e., UHI), thus amplifying SUHI differences between day and night. In addition, climate indirectly affects UHI intensities through regulating vegetation conditions, surface albedo, and anthropogenic heat emissions [54]. This partly explains why Khartoum (warm desert climate) presented a SUCI effect during the daytime, but a positive SUHI at night. Vegetation in the Khartoum urban area compared to bare land in the rural buffer is a possible contributor to the negative annual daytime SUHI [55]. The reversal of the SUHI diurnality in desert cities has been reported elsewhere, e.g., in Las Vegas [56] and Abu Dhabi [57]. During 2003 and 2017, almost all the annual mean SUHI intensities of the cities fit the distribution of decreases with latitudinal increases, except Khartoum and Dar es Salaam. Chakraborty similarly notes latitudinal variation in surface UHI for daytime and night-time [45].

While previous authors [45] used a global analysis algorithm to analyse multiple cities in East Africa in an attempt to develop a standardized data collection approach our research offers additional insight through our statistical analysis. This allows us to extend existing work. Generally, our results in East Africa show the arid urban areas present the 
highest SUHI intensity for night-time, consistent with [45] and [58]. Peng [58] identified the range of annual SUHI intensity in Africa as being from $-0.2\left({ }^{\circ} \mathrm{C}\right)$ to $2.0\left({ }^{\circ} \mathrm{C}\right)$ for daytime, and $0.4\left({ }^{\circ} \mathrm{C}\right)$ to $1.4\left({ }^{\circ} \mathrm{C}\right)$ for night-time. Our results fall outside of this range, spanning -0.44 $\left({ }^{\circ} \mathrm{C}\right)$ to $2.21\left({ }^{\circ} \mathrm{C}\right)$ for day-time and $-0.13\left({ }^{\circ} \mathrm{C}\right)$ to $1.1\left({ }^{\circ} \mathrm{C}\right)$ for night-time. These differences in findings may be down to the selection of different study periods and different land cover data, LandScan from Natural Earth was used by [43] while MODIS Global Land Cover Map was used by [56].

Similar to findings in previous investigations, mean annual daytime SUHI intensities were higher than mean night-time SUHI intensities in most cities. A study in South America found that the mean daytime SUHI intensities was higher than the mean night-time SUHI intensities in all areas except for the arid climate zone [59]. The southeast of China also presents stronger SUHI in the daytime than night-time [60], but the annual mean SUHI intensity was apparently weaker in arid northwest China's cities [6]. The differences between daytime SUHIs and night-time SUHIs are probably because the mechanism of daytime heat island formation is different from that at night. The daytime SUHI was generally explained as the result of an increase in sensible heat flux and a reduction in latent heat flux due to widespread vegetated and evaporating soil surfaces being encroached by impervious surfaces [6], while the release of more stored energy in the urban areas compared to adjacent areas major contribute to night-time SUHI [6]. Compared to 2003, some parts of the cities had a stronger SUHI while some places had a stronger SUCI effect in 2017. This means the temperature differences of all the cities were becoming stronger compared to in the past. Given projected climate changes for East Africa [28], temperatures in large parts of East Africa will continue to rise during the 21st century. This suggests that these already intensified SUHIs will become more complicated. The important role of climate conditions and their diurnal variations in SUHI intensity should not be ignored $[6,61]$ but the changes are also inadequately explained by a focus on climate zones alone.

\subsection{Urbanisation Pattern}

SUHI intensity and magnitude change is also associated with urban development patterns [19], with built-up areas being one of the most important land-cover types in urban areas, and expected to have a significant effect on SUHI [60].

For the case study cities, the pattern of urban expansion and densification explains the change of SUHI intensity to some extent [19]. In Dar es Salaam, there is a highly statistically significant difference (Welch's Test, $p \leq 0.001$ ) in annual daytime SUHI between 2003 and 2017, with a negative size effect (Hedges' $g=-0.48$ ). The statistical results could be explained by the densification of Dar es Salaam. Previous research has also pointed out that Tanzania's urban built-up densities and informal settlements have been growing persistently in recent decades [62].

The urban growth of Addis Ababa and Nairobi reflect an urban expansion development pattern. From 2003 to 2017, the SUHI influenced areas of Addis Ababa expanded from 13,100 ha to 25,400 ha, with a $93.9 \%$ increase. The mean annual daytime and night-time SUHI intensity of Addis Ababa presented a highly statistically significant decrease (Welch's Test, $p \leq 0.001$ ) from 2003 to 2017, but the maximum annual SUHI was higher and the minimum SUHI became lower in 2017 compared to 2003. Similarly, Nairobi is experiencing fast urban expansion. The annual SUHI magnitude of Nairobi saw the greatest changes among the five cities, growing from 4200 ha to 24,200 ha with an increase of $476.9 \%$. The mean annual daytime and night-time SUHI also presented a highly statistically significant decrease (Welch's Test, $p \leq 0.001$ ) between 2003 and 2017. In particular, the Hedges' $g$ values for Nairobi indicate an intermediate size effect in the daytime (Hedges' $g=0.65)$ and strong size effect (Hedges' $g=0.8$ ) in the night-time. In other words, these two cities were experiencing rapid expansion with some places getting hotter and some places getting cooler. Researchers have already pointed out that the built-up area of Addis Ababa and its surrounding towns is expanding into the peri-urban region [63]. This development not only 
influences the SUHI intensity but also leads to high losses of farmland, directly influencing food production for the urban populations [64]. The urban growth in Nairobi was at the cost of bare land (land without any cover as well as deserts), showing a star-shaped pattern along the main transport routes from the city centre [65].

The statistical analysis could indicate the urban development of Kampala and Khartoum followed a more comprehensive pattern, with urban expansion accompanied with densification. For these two cities, there is no significant difference in annual daytime SUHI between 2003 and 2017, with no effect or negative size effect (both Hedges' $\mathrm{g}<0.2$ ). There is no highly significant difference in annual night-time SUHI between 2003 and 2017, with

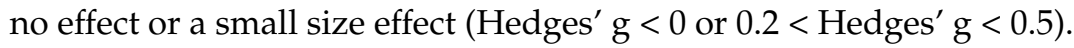

Which kind of urban development pattern is best for the development of cities to reduce any increase in SUHI intensity is still unclear. From this study, we suggest that a compact city will face enhanced SUHI, while an overexpanding city will mitigate mean annual SUHI but cause local thermal anomalies. In Africa, urbanisation has not frequently been associated with economic development and improvements in wellbeing [66], although urbanisation can offer many development opportunities for countries if well managed. Consequently, it is important that further urban development occurs in a way that is beneficial to people, and which does not exacerbate risks associated with climate change, such as increased exposure to temperature extremes.

Policy makers and city planners should pay more attention to one of the main variables influencing rapid urbanisation in Africa: natural rural-urban migration [67]. People migrate to urban areas primarily in response to perceived better employment and economic opportunities available there (pull factors); they also migrate to escape unfavourable conditions exacerbated by rural challenges and climate change (push factors) [68]. The IPCC pointed out that climate change could influence the size and characteristics of human settlements in Africa owing to the scale and type of rural-urban migration are partially driven by climate change [69].

Fast urbanisation sometimes implies a shift of poverty levels from rural areas to urban areas, which is why we see poverty characteristics often align with settlement patterns in African cities, with informal settlements showing particular growth. In Dar es Salaam, over $70 \%$ of the estimated 2.4 million inhabitants lived in informal settlements in 2000 [70], with this number projected to increase to $80 \%$ in the coming decades [71]. Such settlements often experience elevated heat exposure [45,72], as well as other environmental risks, such as greater exposure to pollution [44]. In informal settlements in Nairobi, temperatures regularly exceed temperatures at the central, non-slum monitoring station by several degrees or more [73]. The extra heat exposure experienced by residents of informal settlements, is mainly due to their dense population, tin housing and little vegetation, showing the importance of building materials in contributing to UHI effects. In Kampala, millions of urban inhabitants will live in informal areas by 2030 with high potential for them to suffer from epidemiological diseases related to unsanitary conditions [74]. It is also important to note that urban areas in Africa contain a large proportion of the people who are migrating from rural areas because of climate change impacts, in combination with other factors. Policymakers should consider designing UHI adaptation strategies to minimise its impacts on the most socioeconomically vulnerable populations in informal settlements, who may be less equipped to adapt to environmental stressors. Promoting green space in lower-income neighbourhoods is one appropriate urban strategies that policymakers may adopt to ameliorate some of UHI's inequitable burden on economically disadvantaged inhabitants [72], while encouraging use of building materials with higher heat reflectance offers another strategy (this is explored further below). Improving support for climate change adaptation in the rural source areas of urban immigrants may also be a suitable strategy for policymakers to pursue. 


\subsection{Climate Change and Urbanisation}

Urban areas consume over two-thirds of the world's energy and account for more than $70 \%$ of global CO2 emissions [75]. Moreover, $90 \%$ of urban growth will take place in less developed regions in the coming decades [76], where urbanisation is generally unplanned, fuelling the continuous growth of mostly poor informal settlements in areas such as East Asia, South Asia and sub-Saharan Africa [76]. One billion urban inhabitants are projected to live in informal settlements, where the impact of climate change is most acute [77]. The current urban development deficiency in a form of infrastructure shortfalls, brings opportunities to "leapfrog" to low or zero-emission systems and structures [77]. This implies that a major reconceptualisation of countries' approaches to urban development could still be undertaken. As the World Migration Report [78] notes, about two-thirds of the investments in urban infrastructure to 2050 in Africa have yet to be made, offering an opportunity to manage the urbanisation trends in a way that could harness the benefits of rapid urbanisation while reducing the risks. Combining multiple UHI mitigation and adaptation strategies may effectively negate the localised temperature increasing due to both UHI and climate change [72,79].

Many researchers have noticed the relationship between urban morphology and the UHI intensity $[7,80]$. The morphological characteristics of the city such as building height, building density, road width and orientation may affect the heat balance in urban canyons [80]. In Dar es Salaam, scattered settlements provided better temperature regulation services than other residential configurations due to their urban morphology characteristics, since former are associated with relatively large proportions of green structures [81]. The negative relationship between distance from the city centre and SUHI intensity was detected in Addis Ababa [82]. As noted above, the characteristics of housing materials also influence the SUHI intensity, with different housing types providing different insulation properties and protecting from heat and cold to different extents, even directly impacting on temperature-related mortality [83]. Analysis suggests that traditionally constructed housing provides more protection from heat than formal low-cost housing [83]. This should not be ignored in future African cities development, where the focus is often on upgrading unplanned or informal settlements from traditionally constructed housing [81].

There were various synergies between heat wave and UHI as the varied spatially based on urban development patterns and geographic conditions [84]. Many countries and region have developed other kinds of UHI mitigation strategies for urban development, and beyond looking at entire cities' development, it is important to take the climate condition and climate projections into account at the local scale. For example, in a predominantly alpine climate country Austria, the ADAPT-UHI project developed tools by mapping the potential UHI risk index, modelling different adaptation scenarios, and evaluating and rating cities' quality of existing green and blue infrastructure [81]. Researchers help city planners make decisions on climate change adaptation and minimize the effects of UHI in the future. In the hot desert climate city of Phoenix, Arizona, researchers found that a warming climate was detected to aggravate the interaction between UHI effect and heat waves, while the amplified temperature-exacerbated UHI effect can be almost completely offset by adopting a widespread green roof strategy [85]. In Kampala, a project "Promoting Green Urban Development in Africa: Enhancing the Relationship Between Urbanization, Environmental Assets and Ecosystem Services" conducted under the leadership of the World Bank [86], seeks to conserve the environment as urbanisation proceeds. Addis Ababa is trying to incorporate green infrastructure areas for "multifunctional uses", in order to address stormwater management, UHI mitigation, air filtration, and preservation of urban agriculture [87]. These various approaches offer opportunities for East African cities but require proactive policies and a multi-sector approach to city development [86-88]. Studies of projects that pursue climate compatible development (CCD) in Malawi, South Africa, Tanzania, India and Kenya have revealed such a framework that advances triplewins across development, mitigation and adaptation within the developing world is feasible [89-92]. 
Anticipated additional climate variability and change could further exacerbate disease incidence and spread in East Africa [69]. In East Africa's highlands above $2000 \mathrm{~m}$ altitude, environmental conditions currently do not support malaria transmission. Due to climate change, these areas will experience increased malaria [93]. The changing weather conditions may increase the spread of Rift Valley fever (RVF) virus and could also introduce the RVF virus into domestic animal populations [94]. When considering the use of blue green infrastructure within city development to mitigate UHI effects, local governments should rationally allocate vegetation and water configurations to avoid creating habitats suitable for viral vectors. In addition, for specific climate zones, such as the desert climate zone, understanding its UCI effect (or oasis effect) in urban areas located is important [55]. More than $90 \%$ of the global population residing in deserts and dryland are located in developing countries with high rates of rural to urban migration, indicating that rapid growth in desert cities is likely [95], suggesting further research in this area is urgently needed.

\subsection{Uncertainty, Limitations and Further Considerations}

Our research has focused only on the annual UHI. This decision was made primarily due to the different classification of seasons in Africa between study countries. For comparability we therefore chose to present the annual UHI trends in our study cities. We recognise that there may be specific climate features of each selected study year, and our results can only represent the differences between those two selected years. This provides important insights but from the analysis undertaken, we cannot make robust claims about long-term change [45].

Topography, morphology and biodiversity, are well known to influence UHI effects but were not directly measured in this research [96]. We have nevertheless identified their potential contributions when explaining our results. As with all UHI modelling approaches, the model output's reliability is strongly reliant on the definition and boundary-setting of urban areas. In particular, there remain challenges in integrating data from the Global Surface UHI Explorer with the global-scale Landscan urban extent dataset, as in terms of missing data for certain months or years, limiting the ability to explore dynamic changes in SUHI associated with urbanisation.

Despite these limitations, this paper has contributed novel empirical information and applied a method that enables comparison across different East African cities, offering an approach that is widely applicable. The method can be used to identify changes in smaller African cities as well as the capital cities considered in this research. Such insights would be particularly valuable in smaller cities where urbanisation is most rapidly accelerating [1].

\section{Conclusions}

The ongoing effects of UHI in rapidly urbanising cities, further exacerbated by global climate change, have intensified heat stress for countless urban inhabitants, especially those who are most vulnerable during heatwave events. We investigated the SUHI in five East African study cities across various climate zones in 2003 and 2017. SUHI intensities differed between day and night, and mean annual daytime SUHI intensities were higher than the mean night-time SUHI intensities in most cities. Results revealed that the differences in climate conditions and urban development patterns had a significant impact on the changes to the SUHI. Policy makers and city planners should consider UHI mitigation strategies, taking into account climate conditions, projected climate changes and urban development patterns, as well as the implications of informal settlement growth. Blue and green infrastructure, in general, constitutes an essential means for mitigating urban heat and enhancing human comfort, but this needs to be carefully planned to avoid negative impacts linked to human wellbeing and the spread of disease.

Author Contributions: Conceptualization, X.L., L.C.S. and M.D.; methodology, X.L., L.C.S. and M.D.; software, X.L.; formal analysis, X.L.; writing-original draft preparation, X.L.; writing-review and editing, L.C.S. and M.D.; supervision, L.C.S. and M.D.; All authors have read and agreed to the published version of the manuscript. 
Funding: This research was funded by UK government's Natural Environment Research Council (NERC), grant number NE/R002681/1. X.L. was funded by a scholarship (Fujian-Taiwan Joint Innovative Centre for Germplasm Resources and Cultivation of Crop (grant No. 2015-75. Fujian 2011 Program, China).

Data Availability Statement: Original SUHI data used in this study have been obtained from https:/ / yceo.users.earthengine.app/view/uhimap (accessed on 3 May 2020) and city centre data on Figure 3 are from https: / /www.naturalearthdata.com/ (accessed on 30 May 2020).

Acknowledgments: Thank you to the reviewers for their helpful comments in improving this manuscript.

Conflicts of Interest: The authors declare no conflict of interest. The funders had no role in the design of the study; in the collection, analyses, or interpretation of data; in the writing of the manuscript, or in the decision to publish the results.

\section{References}

1. DESA. World Population Prospects 2019 Highlights. Available online: https://population.un.org/wpp/Publications/Files/ WPP2019_Highlights.pdf (accessed on 15 December 2020).

2. Howard, L. The Climate of London: Deduced from Meteorological Observations Made in the Metropolis and at Various Places around It; Harvey and Darton: London, UK, 1833.

3. Oke, T.R. The energetic basis of the urban heat island. Q. J. R. Meteorol. Soc. 1982, 108, 1-24. [CrossRef]

4. Oke, T.R. City size and the urban heat island. Atmos. Env. 1973, 7, 769-779. [CrossRef]

5. Li, Y.; Schubert, S.; Kropp, J.P.; Rybski, D. On the influence of density and morphology on the Urban Heat Island intensity. Nat. Commun. 2020, 11, 2647. [CrossRef]

6. Zhou, D.; Zhao, S.; Liu, S.; Zhang, L.; Zhu, C. Surface urban heat island in China's 32 major cities: Spatial patterns and drivers. Remote Sens. Environ. 2014, 152, 51-61. [CrossRef]

7. He, B.-J.; Ding, L.; Prasad, D. Relationships among local-scale urban morphology, urban ventilation, urban heat island and outdoor thermal comfort under sea breeze influence. Sustain. Cities Soc. 2020,60, 102289. [CrossRef]

8. Grimm, N.B.; Faeth, S.H.; Golubiewski, N.E.; Redman, C.L.; Wu, J.; Bai, X.; Briggs, J.M. Global change and the ecology of cities. Sci. Am. Assoc. Adv. Sci. 2008, 319, 756-760. [CrossRef]

9. Holloway, T.; Patz, J.A.; Campbell-Lendrum, D.; Foley, J.A. Impact of regional climate change on human health. Nature 2005, 438, 310-317. [CrossRef]

10. Bouchama, A. The 2003 European heat wave. Intensive Care Med. 2004, 30, 1-3. [CrossRef]

11. Argüeso, D.; Evans, J.P.; Fita, L.; Bormann, K.J. Temperature response to future urbanization and climate change. Clim. Dyn. 2014, 42, 2183-2199. [CrossRef]

12. Cai, M.; Kalnay, E. Impact of urbanization and land-use change on climate. Nature 2003, 423, 528-531. [CrossRef]

13. Georgescu, M.; Moustaoui, M.; Mahalov, A.; Dudhia, J. Summer-time climate impacts of projected megapolitan expansion in Arizona. Nat. Clim. Chang. 2013, 3, 37-41. [CrossRef]

14. Chen, X.; Zhao, H.-M.; Li, P.-X.; Yin, Z.-Y. Remote sensing image-based analysis of the relationship between urban heat island and land use/cover changes. Remote Sens. Environ. 2006, 104, 133-146. [CrossRef]

15. Heusinkveld, B.G.; Steeneveld, G.J.; Hove, V.L.W.A.; Jacobs, C.M.J.; Holtslag, A.A.M. Spatial variability of the Rotterdam urban heat island as influenced by urban land use. J. Geophys. Res. Atmos. 2014, 119, 677-692. [CrossRef]

16. Kikon, N.; Singh, P.; Singh, S.K.; Vyas, A. Assessment of urban heat islands (UHI) of Noida City, India using multi-temporal satellite data. Sustain. Cities Soc. 2016, 22, 19-28. [CrossRef]

17. Dominguez, F.; Villegas, J.C.; Breshears, D.D. Spatial extent of the North American Monsoon: Increased cross-regional linkages via atmospheric pathways. Geophys. Res. Lett. 2009, 36. [CrossRef]

18. Krayenhoff, E.S.; Moustaoui, M.; Broadbent, A.M.; Gupta, V.; Georgescu, M. Diurnal interaction between urban expansion, climate change and adaptation in US cities. Nat. Clim. Chang. 2018, 8, 1097-1103. [CrossRef]

19. Chapman, S.; Watson, J.E.M.; Salazar, A.; Thatcher, M.; McAlpine, C.A. The impact of urbanization and climate change on urban temperatures: A systematic review. Landsc. Ecol. 2017, 32, 1921-1935. [CrossRef]

20. Njoh, A.J. The experience and legacy of French colonial urban planning in sub-Saharan Africa. Plan. Perspect. 2004, 19, 435-454. [CrossRef]

21. Anas, A.; Rhee, H.-J. Curbing excess sprawl with congestion tolls and urban boundaries. Reg. Sci. Urban Econ. 2006, 36, 510-541. [CrossRef]

22. Cobbinah, P.B.; Aboagye, H.N. A Ghanaian twist to urban sprawl. Land Use Policy 2017, 61, 231-241. [CrossRef]

23. Chapman, S.; Thatcher, M.; Salazar, A.; James, E.M.W.; McAlpine, C.A. The effect of urban density and vegetation cover on the heat island of a subtropical city. J. Appl. Meteorol. Climatol. 2018, 57, 2531-2550. [CrossRef]

24. Seto, K.C.; Fragkias, M.; Güneralp, B.; Reilly, M.K. A meta-analysis of global urban land expansion. PLoS ONE 2011,6 , e23777. [CrossRef] 
25. Fataar, R. Densification and the Ambition for a Democratic City. Available online: https://ethz.ch/content/dam/ethz/specialinterest/conference-websites-dam/no-cost-housing-dam/documents/Fataar_Densificationandtheambitionforademocraticcity_ RashiqFataar.pdf (accessed on 3 December 2020).

26. Todes, A.; Weakley, D.; Harrison, P. Densifying Johannesburg: Context, policy and diversity. J. Hous. Built Environ. 2018, 33, 281-299. [CrossRef]

27. Samarrai, F. Study: 'Unbearable' Heat Stress to Affect East Africans by Late 21St Century. Available online: https:/ / news.virginia. edu/content/study-unbearable-heat-stress-affect-east-africans-late-21st-century-0 (accessed on 15 December 2020).

28. Gebrechorkos, S.H.; Hülsmann, S.; Bernhofer, C. Regional climate projections for impact assessment studies in East Africa. Environ. Res. Lett. 2019, 14, 044031. [CrossRef]

29. Anyah, R.O.; Qiu, W. Characteristic 20th and 21st century precipitation and temperature patterns and changes over the Greater Horn of Africa. Int. J. Climatol. 2012, 32, 347-363. [CrossRef]

30. Brown, M.E.; Brickley, E.B. Evaluating the use of remote sensing data in the US agency for international development famine early warning systems network. J. Appl. Remote Sens. 2012, 6, 063511. [CrossRef]

31. Conway, D.; Schipper, E.L.F. Adaptation to climate change in Africa: Challenges and opportunities identified from Ethiopia. Glob. Environ. Chang. 2011, 21, 227-237. [CrossRef]

32. Sun, R.; Lü, Y.; Yang, X.; Chen, L. Understanding the variability of urban heat islands from local background climate and urbanization. J. Clean. Prod. 2019, 208, 743-752. [CrossRef]

33. Seto, K.C.; Güneralp, B.; Hutyra, L.R. Global forecasts of urban expansion to 2030 and direct impacts on biodiversity and carbon pools. Proc. Natl. Acad. Sci. USA 2012, 109, 16083. [CrossRef]

34. Beck, H.E.; Zimmermann, N.E.; McVicar, T.R.; Vergopolan, N.; Berg, A.; Wood, E.F. Present and future Köppen-Geiger climate classification maps at 1-km resolution. Sci. Data 2018, 5, 1. [CrossRef]

35. Osman, M.M.; Sevinc, H. Adaptation of climate-responsive building design strategies and resilience to climate change in the hot/arid region of Khartoum, Sudan. Sustain. Cities Soc. 2019, 47, 101429. [CrossRef]

36. Zerboni, A.; Brandolini, F.; Mariani, G.S.; Perego, A.; Salvatori, S.; Usai, D.; Pelfini, M.; Williams, M.A. The Khartoum-Omdurman conurbation: A growing megacity at the confluence of the Blue and White Nile Rivers. J. Maps 2020, 1-14. [CrossRef]

37. Ndetto, E.L.; Matzarakis, A. Basic analysis of climate and urban bioclimate of Dar es Salaam, Tanzania. Theor. Appl. Climatol. 2013, 114, 213-226. [CrossRef]

38. Egondi, T.; Kyobutungi, C.; Rocklöv, J. Temperature variation and heat wave and cold spell impacts on years of life lost among the urban poor population of Nairobi, Kenya. Int. J. Environ. Res. Public Health 2015, 12, 2735-2748. [CrossRef]

39. Oyugi, M.O.; Odenyo, V.A.; Karanja, F.N. The implications of land use and land cover dynamics on the environmental quality of Nairobi City, Kenya. Am. J. Geogr. Inf. Syst. 2017, 6, 111-127. [CrossRef]

40. (KNBS), K.N.B.o.S. Republic of Kenya Population and Census Survey 2009; Ministry of Planning: Nairobi, Kenya, 2010.

41. Angassa, K.; Leta, S.; Mulat, W.; Kloos, H. Seasonal characterization of municipal wastewater and performance evaluation of a constructed wetland system in Addis Ababa, Ethiopia. Int. J. Energy Water Resour. 2020, 4, 127-138. [CrossRef]

42. Feyisa, G.L.; Dons, K.; Meilby, H. Efficiency of parks in mitigating urban heat island effect: An example from Addis Ababa. Landsc. Urban Plan. 2014, 123, 87-95. [CrossRef]

43. Kabano, P.; Lindley, S.; Harris, A. Evidence of urban heat island impacts on the vegetation growing season length in a tropical city. Landsc. Urban Plan. 2021, 206, 103989. [CrossRef]

44. Richmond, A.; Myers, I.; Namuli, H. Urban Informality and Vulnerability: A Case Study in Kampala, Uganda. Urban Sci. 2018, 2, 22. [CrossRef]

45. Chakraborty, T.; Lee, X. A simplified urban-extent algorithm to characterize surface urban heat islands on a global scale and examine vegetation control on their spatiotemporal variability. Int. J. Appl. Earth Obs. Geoinf. 2019, 74, 269-280. [CrossRef]

46. Moser, B.K.; Stevens, G.R. Homogeneity of variance in the two-sample means test. Am. Stat. 1992, 46, 19-21. [CrossRef]

47. McGraw, K.O.; Wong, S.P. A common language effect size statistic. Psychol. Bull. 1992, 111, 361-365. [CrossRef]

48. Cohen, J. Statistical Power Analysis for the Behavioral Sciences; Lawrence Erlbaum Associates: New York, NY, USA, 1988; ISBN 0805802835.

49. Lenhard, W.; Lenhard, A. Calculation of Effect Sizes. Available online: https://www.psychometrica.de/effect_size.html (accessed on 4 June 2020).

50. Ellis, P.D. The Essential Guide to Effect Sizes: Statistical Power, Meta-Analysis, and the Interpretation of Research Results; Cambridge University Press: Cambridge, UK, 2010.

51. Team, R.; RStudio: Integrated Development for R. RStudio. Available online: http:/ /www.rstudio.com/ (accessed on 6 June 2020).

52. Tran, H.; Uchihama, D.; Ochi, S.; Yasuoka, Y. Assessment with satellite data of the urban heat island effects in Asian mega cities. Int. J. Appl. Earth Obs. Geoinf. 2006, 8, 34-48. [CrossRef]

53. Chow, W.T.; Roth, M. Temporal dynamics of the urban heat island of Singapore. Int. J. Climatol. A J. R. Meteorol. Soc. 2006, 26, 2243-2260. [CrossRef]

54. Santamouris, M.; Papanikolaou, N.; Livada, I.; Koronakis, I.; Georgakis, C.; Argiriou, A.; Assimakopoulos, D. On the impact of urban climate on the energy consumption of buildings. Sol. Energy 2001, 70, 201-216. [CrossRef] 
55. Rindfuss, R.R.; Myint, S.; Brazel, A.; Fan, C.; Zheng, B. Urban heat islands: Global variation and determinants in hot desert and hot semi-arid desert cities. In Proceedings of the Population Association of America 2016 Annual Meeting, Washington, DC, USA, 31 Mar-2 April 2016.

56. Imhoff, M.L.; Zhang, P.; Wolfe, R.E.; Bounoua, L. Remote sensing of the urban heat island effect across biomes in the continental USA. Remote Sens. Environ. 2010, 114, 504-513. [CrossRef]

57. Lazzarini, M.; Marpu, P.R.; Ghedira, H. Temperature-land cover interactions: The inversion of urban heat island phenomenon in desert city areas. Remote Sens. Environ. 2013, 130, 136-152. [CrossRef]

58. Peng, S.; Piao, S.; Ciais, P.; Friedlingstein, P.; Ottle, C.; Bréon, F.-M.; Nan, H.; Zhou, L.; Myneni, R.B. Surface urban heat island across 419 global big cities. Environ. Sci. Technol. 2012, 46, 696-703. [CrossRef] [PubMed]

59. Wu, X.; Wang, G.; Yao, R.; Wang, L.; Yu, D.; Gui, X. Investigating surface urban heat islands in south america based on MODIS data from 2003-2016. Remote Sens. 2019, 11, 1212. [CrossRef]

60. Yang, Q.; Huang, X.; Li, J. Assessing the relationship between surface urban heat islands and landscape patterns across climatic zones in China. Sci. Rep. 2017, 7, 1-11. [CrossRef]

61. Chieppa, J.; Bush, A.; Mitra, C. Using “Local Climate Zones" to detect urban heat island on two small cities in alabama. Earth Interact. 2018, 22, 1-22. [CrossRef]

62. Bhanjee, S.; Zhang, C.H. Mapping latest patterns of urban sprawl in dar es salaam, tanzania. Pap. Appl. Geogr. 2018, 4, 292-304. [CrossRef]

63. Kassa, F. Conurbation and urban sprawl in Africa: The case of the City of Addis Ababa. Ghana J. Geogr. 2013, 5, 73-89.

64. Abo-El-Wafa, H.; Yeshitela, K.; Pauleit, S. Exploring the future of rural-urban connections in sub-Saharan Africa: Modelling urban expansion and its impact on food production in the Addis Ababa region. Geogr. Tidsskr. 2017, 117, 68-81. [CrossRef]

65. Hou, H.; Estoque, R.C.; Murayama, Y. Spatiotemporal analysis of urban growth in three African capital cities: A grid-cell-based analysis using remote sensing data. J. Afr. Earth Sci. 2016, 123, 381-391. [CrossRef]

66. Du Toit, M.J.; Cilliers, S.S.; Dallimer, M.; Goddard, M.; Guenat, S.; Cornelius, S.F. Urban green infrastructure and ecosystem services in sub-Saharan Africa. Landsc. Urban Plan. 2018, 180, 249-261. [CrossRef]

67. Hope, S.K.R. Climate change and urban development in Africa. Int. J. Environ. Stud. 2009, 66, 643-658. [CrossRef]

68. Yuen, B.; Kumssa, A. Climate Change and Sustainable Urban Development in Africa and Asia; Springer: Dordrecht, The Netherlands, 2010.

69. Niang, I.; Ruppel, O.C.; Abdrabo, M.A.; Essel, A.; Lennard, C.; Padgham, J.; Urquhart, P. Africa. In Climate Change 2014-Impacts, Adaptation and Vulnerability: Part B: Regional Aspects Working Group II Contribution to the IPCC Fifth Assessment Report; Barros, V.R., Field, C.B., Estrada, Y.O., Genova, R.C., Girma, B., Kissel, E.S., Levy, A.N., MacCracken, S., Mastrandrea, P.R., White, L.L., Eds.; Cambridge University Press: Cambridge, UK, 2014; pp. 1199-1265.

70. Kombe, W.J.; Kreibich, V. Informal Land Management in Tanzania. SPRING Centre, Faculty of Spatial Plannning; University of Dortmund: Dortmund, Germany, 2000.

71. Augustijn-Beckers, E.-W.; Flacke, J.; Retsios, B. Simulating informal settlement growth in Dar es Salaam, Tanzania: An agent-based housing model. Comput. Environ. Urban Syst. 2011, 35, 93-103. [CrossRef]

72. Chakraborty, T.; Hsu, A.; Manya, D.; Sheriff, G. Disproportionately higher exposure to urban heat in lower-income neighborhoods: A multi-city perspective. Environ. Res. Lett. 2019, 14, 105003. [CrossRef]

73. Scott, A.A.; Misiani, H.; Okoth, J.; Jordan, A.; Gohlke, J.; Ouma, G.; Arrighi, J.; Zaitchik, B.F.; Jjemba, E.; Verjee, S. Temperature and heat in informal settlements in Nairobi. PLoS ONE 2017, 12, e0187300. [CrossRef]

74. Vermeiren, K.; Van Rompaey, A.; Loopmans, M.; Serwajja, E.; Mukwaya, P. Urban growth of Kampala, Uganda: Pattern analysis and scenario development. Landsc. Urban Plan. 2012, 106, 199-206. [CrossRef]

75. World Bank Group. Urban Development. Available online: https://www.worldbank.org/en/topic/urbandevelopment/ overview\#1 (accessed on 11 December 2020).

76. United Nation. 2018 Revision of World Urbanization Prospects. Available online: https://population.un.org/wup/Publications/ Files/WUP2018-Report.pdf (accessed on 29 December 2020).

77. UN-Habitat. Addressing the Most Vulnerable First: Pro-Poor Climate Action in Informal Settlements. Available online: https: / / www.preventionweb.net/publications/view/62059 (accessed on 22 December 2020).

78. Awumbila, M. World Migration Report 2015: Linkages between Urbanization, Rural-Urban Migration and Poverty Outcomes in Africa. Available online: https://publications.iom.int/system/files/wmr2015_en.pdf (accessed on 21 December 2020).

79. Zhao, L.; Lee, X.; Schultz, N. A wedge strategy for mitigation of urban warming in future climate scenarios. Atmos. Chem. Phys. Discuss. 2017, 1-28. [CrossRef]

80. Zhou, X.; Chen, H. Impact of urbanization-related land use land cover changes and urban morphology changes on the urban heat island phenomenon. Sci. Total Environ. 2018, 635, 1467-1476. [CrossRef] [PubMed]

81. Cavan, G.; Lindley, S.; Jalayer, F.; Yeshitela, K.; Pauleit, S.; Renner, F.; Gill, S.; Capuano, P.; Nebebe, A.; Woldegerima, T.; et al. Urban morphological determinants of temperature regulating ecosystem services in two African cities. Ecol. Indic. 2014, $42,43-57$. [CrossRef]

82. Feyisa, G.L.; Meilby, H.; Jenerette, G.D.; Pauliet, S. Locally optimized separability enhancement indices for urban land cover mapping: Exploring thermal environmental consequences of rapid urbanization in Addis Ababa, Ethiopia. Remote Sens. Environ. 2016, 175, 14-31. [CrossRef] 
83. Scovronick, N.; Armstrong, B. The impact of housing type on temperature-related mortality in South Africa, 1996-2015. Environ. Res. 2012, 113, 46-51. [CrossRef]

84. He, B.-J.; Wang, J.; Liu, H.; Ulpiani, G. Localized synergies between heat waves and urban heat islands: Implications on human thermal comfort and urban heat management. Environ. Res. 2021, 193, 110584. [CrossRef] [PubMed]

85. Tewari, M.; Yang, J.; Kusaka, H.; Salamanca, F.; Watson, C.; Treinish, L. Interaction of urban heat islands and heat waves under current and future climate conditions and their mitigation using green and cool roofs in New York City and Phoenix, Arizona. Environ. Res. Lett. 2019, 14, 034002. [CrossRef]

86. White, R.; Turpie, J.; Letley, G.L. Greening Africa's Cities: Enhancing the Relationship between Urbanization, Environmental Assets, and Ecosystem Services; World Bank: Washington, DC, USA, 2017.

87. Larsen, L. Urban climate and adaptation strategies. Front. Ecol. Environ. 2015, 13, 486-492. [CrossRef]

88. UN-Habitat. UN-Habitat and Sudan sign Country Programme Document. Available online: https://www.developmentaid.org/ \#!/news-stream/post/25698/un-habitat-and-sudan-sign-country-programme-document (accessed on 13 December 2020).

89. Stringer, L.C.; Dougill, A.J.; Dyer, J.C.; Vincent, K.; Fritzsche, F.; Leventon, J.; Falcao, M.P.; Manyakaidze, P.; Syampungani, S.; Powell, P. Advancing climate compatible development: Lessons from southern Africa. Reg. Environ. Chang. 2014, 14, 713-725. [CrossRef]

90. Colenbrander, S.; Gouldson, A.; Roy, J.; Kerr, N.; Sarkar, S.; Hall, S.; Sudmant, A.; Ghatak, A.; Chakravarty, D.; Ganguly, D. Can low-carbon urban development be pro-poor? The case of Kolkata, India. Environ. Urban. 2017, 29, 139-158. [CrossRef]

91. Wanjiru, C.; Nunan, F. Enabling climate compatible development in the coastal region of Kenya. In Making Climate Compatible Development Happen; Taylor \& Francis, Routledge: London, UK, 2017; pp. 223-244.

92. Ficklin, L.; Wood, B.T.; Dougill, A.J.; Sallu, S.M.; Stringer, L.C. Reconsidering climate compatible development as a new development landscape in Southern Africa. In Making Climate Compatible Development Happen; Taylor \& Francis, Routledge: London, UK, 2017; pp. 44-65.

93. Alonso, D.; Bouma, M.J.; Pascual, M. Epidemic malaria and warmer temperatures in recent decades in an East African highland. Proc. R. Soc. B Biol. Sci. 2011, 278, 1661-1669. [CrossRef] [PubMed]

94. Baba, M.; Masiga, D.K.; Sang, R.; Villinger, J. Has Rift Valley fever virus evolved with increasing severity in human populations in East Africa? Emerg. Microbes Infect. 2016, 5, 1-10. [CrossRef] [PubMed]

95. UN-EMG. 2010-2020: UN Decade for Deserts and the Fight against Desertification. Available online: https://www.un.org/en/ events/desertification_decade/value.shtml (accessed on 13 December 2020).

96. Hamada, S.; Tanaka, T.; Ohta, T. Impacts of land use and topography on the cooling effect of green areas on surrounding urban areas. Urban For. Urban Green. 2013, 12, 426-434. [CrossRef] 